\title{
Appendicitis in Low-Resource Settings
}

\author{
Kovi E. Bessoff and Joseph D. Forrester
}

\begin{abstract}
Background: Acute appendicitis is one of the most common surgical emergencies globally. Its incidence is increasing in low- and middle-Human Development Index countries (LMHDICs). Although a proportion of patients can be treated successfully with non-operative management consisting of antibiotics, supportive therapy, and close observation, current diagnostic algorithms lack the granularity to identify these patients accurately. Methods: We reviewed published literature describing practice patterns and clinical outcomes for appendicitis in LMHDICs and compared them with studies from high-Human Development Index countries, as well as guidelines published by international surgical societies.

Results: We identified shortcomings in current diagnostic and therapeutic strategies used in LMHDICs. Delays in obtaining surgical care inherent in many LMHDIC healthcare systems make prompt surgical care the mainstay for the treatment of acute appendicitis. Laparoscopic appendectomy leads to better outcomes than open appendectomy in resource-constrained settings and when available should be the surgical technique of choice.

Conclusions: Acute appendicitis is common in LMHDICs, and if possible, laparoscopic appendectomy should be the procedure of choice.
\end{abstract}

Keywords: appendectomy; appendicitis; developing world; surgery

A PPENDICITIS is one of the most common surgical emergencies globally. Despite its ubiquitous nature, epidemiologic understanding of the disease remains incomplete. The lifetime risk of acute appendicitis in the United States has been estimated at $8.6 \%$ in men and $6.7 \%$ in women [1]. Whereas the pooled incidence of the disease has been decreasing in the United States, Europe, and Oceania since the 1990s, it has increased in low- and middle-Human Development-Index countries (LMHDICs) [2]. Although the exact reason for this discrepancy is unknown, a number of factors may be responsible.

Dietary fiber content has been postulated to correlate with development of appendicitis [3,4]. At least one theory posits dietary patterns associated with urbanization contribute to the increasing incidence in LMHDICs [4]. Additionally, environmental pollutants correlate with a higher incidence of appendicitis [5,6], suggesting a connection between appendicitis and pollution from urban industrial development [7]. More recent work implicates intestinal dysbiosis, or changes in the human intestinal microbiome, as a driver of disease. Zhong et al. [8] noted a correlation between certain intestinal micro-organisms and appendicitis, and other work [9] demonstrated a correlation between disease incidence and invasion of the appendiceal mucosa by fusobacteria in a geographically diverse patient cohort.
Immune alterations also correlate with appendicitis. Differential expression of human genes, including paired like homeodomain 2 (PITX2), have been linked to appendicitis [10], while temporal and spatial clustering of appendicitis cases suggests an infectious etiology for the disease [11-13]. However, researchers have been unable to identify specific inciting agents [13]. Given clear temporal and geographical trends, and the presumed role of reactive lymphadenopathy in the pathophysiology of appendicitis, it is feasible that dense living conditions and suboptimal hygiene in developing countries facilitate spread of predisposing infections. Regardless of etiology, shifting trends in incidence highlight the need for an evidence-based approach to inform diagnosis and management of acute appendicitis in resource-constrained settings.

\section{Pathophysiology of Appendicitis}

Optimal management of appendicitis is further complicated by an incomplete grasp of the disease's pathophysiology. Appendicitis generally is believed to result from obstruction of the appendiceal lumen by a fecalith, hypertrophied lymphatic tissue, or, less commonly, carcinoid tumor or intestinal parasites [1]. This results in a spectrum of disease ranging from local inflammation (uncomplicated appendicitis) to

Division of General Surgery, Department of Surgery, Stanford University, Stanford, California, USA. 
frank gangrene and appendiceal perforation (complicated appendicitis). Although classic teaching suggests appendicitis is a progressive disease that begins uncomplicated and evolves into complicated disease in the absence of treatment, there is evidence that these clinical outcomes represent separate disease entities entirely. The rate of uncomplicated appendicitis differs with a number of covariates, whereas that of perforated appendicitis does not [14], suggesting different etiologies of disease. Additionally, increases in perforated appendicitis cases despite a sustained decrease in uncomplicated cases [15] supports the entities having different natural histories. A retrospective review of 9,000 patients with acute appendicitis showed no correlation between elapsed time to appendectomy and the risk of appendiceal perforation [16], raising questions around the traditional model of time-dependent development of complicated appendicitis. Finally, genetic factors may play a role, as a single nucleotide polymorphism (SNP) in the interleukin-6 (IL6) gene may be protective against complicated appendicitis [17].

\section{Clinical Management of Appendicitis: Non-Operative Procedures}

Uncomplicated and complicated appendicitis may result in different clinical outcomes. The former is mainly selfresolving or can be treated effectively with antibiotics $[18,19]$, whereas the latter carries a substantial risk of morbidity and death [20-22] if not treated expeditiously with surgical intervention. Consequently, it is not unreasonable to consider different clinical management algorithms for these diseases. Non-operative management in certain patients with uncomplicated appendicitis can reduce the risk of major and minor complications [18], leading to recommendations by the World Society of Emergency Surgery (WSES) for nonoperative management in carefully selected patients [23]. However, the European Association of Endoscopic Surgery (EAES) does not recommend non-operative management of appendicitis with antibiotics, noting that "high quality evidence of superiority is still lacking" [24]. If non-operative management is pursued, adequate follow-up is essential, as these patients have a $13.9 \%$ [19] to $39 \%$ [25] risk of recurrence within five years. Nonetheless, non-operative management may help decrease the rate of negative appendectomy, which has been linked to higher complication rates than appendectomies carried out for histologically confirmed appendicitis [26,27]. Although clinical management differs according to where patients present on the clinical spectrum, there is little consensus as to which clinical, radiographic, pathologic, and operative findings differentiate uncomplicated from complicated appendicitis [28].

\section{Diagnosis of Appendicitis}

Appropriate clinical management of appendicitis hinges on accurate diagnosis and assessment of disease severity. A number of clinical prediction rules (CPRs) have been described [29-38] (Table 1). The Alvarado (MANTRELS) score [29] is the best known. The Alvarado system has been widely studied in high-Development Index countries (HDICs), and the results of a large meta-analysis [39] showed that it can rule out appendicitis accurately but lacks precision in ruling in appendectomy candidates. Other CPRs are the
Appendicitis Inflammatory Response (AIR) Score [30], the Ramathibodi Appendicitis Score (RAMA-AS) [37], and the pediatric appendicitis score (PAS) [34]. A recent metaanalysis by Kularatna et al. [40] identified 12 CPRs (inclusive of the Alvarado and AIR scores) for diagnosing adult appendicitis and concluded that the AIR was the most performant and pragmatic.

Although CPRs are helpful in establishing a diagnosis of appendicitis, they are less useful in determining disease severity $[41,42]$. This has led to the testing of additional biomarkers and refinement of CPRs aimed at differentiating complicated and uncomplicated disease. Laboratory values including the delta neutrophil index (DNI) [38], C-reactive protein, and white blood cell (WBC) count have been used as biomarkers in combination with clinical and imaging data for this purpose [38,43-46] (Table 2). The WSES has determined that although useful as triage tools, no current CPR achieves adequate performance reliably to identify patients who warrant appendectomy [23]. Nonetheless, both the WSES and EAES [24] recommend stratification of patients by CPR as a first step in management.

\section{Applicability of Diagnostic Algorithms to LMHDICs}

The generalizability of these tools to LMHDICs is unclear. The overwhelming majority of CPRs are based on data gathered in HDIC populations. Of the 12 CPRs identified by Kularatna et al. [40] in their meta-analysis, none was derived from an LMHDIC population. This is particularly important given that different CPRs exhibit variable performance when applied to different populations. For example, the Raja Isteri Pengiran Anak Saleha Appendicitis (RIPASA) score outperforms the Alvarado score in Asian [35] and Indian [47] populations. Additionally, in a retrospective review of 1,000 black South Africans [48], more than one quarter of patients with histologically confirmed appendicitis would have been classified as low or intermediate probability by the Alvarado score, and $5 \%$ of patients with confirmed appendicitis would have been discharged without treatment. However, the Modified Alvarado Scoring System (MASS; which differs from the Alvarado score in that it does not consider the presence of left shift) had a sensitivity of $94.1 \%$ and a specificity of $90.4 \%$ for acute appendicitis in a Tanzanian patient cohort [49]. A number of factors may help explain discrepancies in CPRs between patient populations. For example, unlike the Alvarado score, RIPASA incorporates age, gender, and duration of symptoms, suggesting differential weights of variables in specific populations. Moreover, LMHDICs have a greater proportion of pediatric patients [50], which may limit the value of extrapolation [51].

Other disease processes prevalent in LMHDIC settings may produce similar clinical prodromes, further complicating diagnosis. A range of pathologic agents, including Trichuris trichuria, amoebiasis, ascaris, and Enterobius vermicularis, have been identified in patients who underwent incidental appendectomy [52], demonstrating the ability of multiple tropical infections to masquerade as acute appendicitis. Salmonella typhi infection (typhoid fever) also may present with severe right lower-quadrant pain [53]. In areas with high rates of human immunodeficiency virus infection, abdominal tuberculosis may co-occur with, or mimic, the symptoms of 
Table 1. Clinical Prediction Rules to Aid in Diagnosis of Appendicitis

\begin{tabular}{|c|c|c|c|c|}
\hline Scoring System & Citation & Criteria & Points & Interpretation \\
\hline $\begin{array}{l}\text { Alvarado Score } \\
\text { (MANTRELS) }\end{array}$ & $\begin{array}{l}\text { Alvarado } 1986 \\
\text { [29] }\end{array}$ & $\begin{array}{l}\text { Migration of pain to right lower } \\
\text { quadrant } \\
\text { Anorexia } \\
\text { Nausea/vomiting } \\
\text { Tenderness in right lower quadrant } \\
\text { Rebound pain } \\
\text { Elevated temperature }\left(>99.1^{\circ} \mathrm{F} ;\right. \\
\left.37.3^{\circ} \mathrm{C}\right) \\
\text { Leukocytosis }(>10,000 \\
\left.\text { WBC/ } \mathrm{mm}^{3}\right) \\
\text { Shift of WBC count to left }(>75 \%)\end{array}$ & $\begin{array}{l}1 \\
1 \\
1 \\
2 \\
1 \\
1\end{array}$ & $\begin{array}{l}5 \text { or } 6 \text { points: "compatible with } \\
\text { the diagnosis of acute appendi- } \\
\text { citis" } 7 \text { or } 8 \text { points: "probable } \\
\text { appendicitis" } 9 \text { or } 10 \text { points: } \\
\text { "very probable appendicitis" }\end{array}$ \\
\hline $\begin{array}{l}\text { Appendicitis } \\
\text { Inflammatory } \\
\text { Response Score }\end{array}$ & $\begin{array}{l}\text { Andersson and } \\
\text { Andersson } \\
2008[30]\end{array}$ & $\begin{array}{l}\text { Vomiting } \\
\text { Pain in right iliac fossa } \\
\text { Rebound tenderness } \\
\text { Light } \\
\text { Medium } \\
\text { Strong } \\
\text { Temperature } \geq 38.5^{\circ} \mathrm{C} \\
\text { Proportion }(\%) \text { of } \\
\quad \text { polymorphonuclear leukocytes } \\
70-84 \\
\geq 84 \\
\text { White blood cell count } \\
10.0-14.9 \times 10^{9} / \mathrm{L} \\
\geq 15.0 \times 10^{9} / \mathrm{L}\end{array}$ & $\begin{array}{l}1 \\
1 \\
1 \\
2 \\
3 \\
1\end{array}$ & $\begin{array}{l}\text { Score }<5 \text { : low probability } \\
\text { Score 5-8: indeterminate result } \\
\text { Score }>8 \text { : high probability }\end{array}$ \\
\hline APPEND Score & $\begin{array}{l}\text { Mikaere et al. } \\
2018 \text { [31] }\end{array}$ & $\begin{array}{l}\text { Anorexia } \\
\text { Migratory pain } \\
\text { Localized peritonism } \\
\text { Elevated CRP }(\geq 15 \mathrm{mg} / \mathrm{L}) \\
\text { Neutrophilia }\left(>7.5 \times 10^{9} / \mathrm{L}\right) \\
\text { Male gender }\end{array}$ & $\begin{array}{l}1 \\
1 \\
1 \\
1 \\
1 \\
1\end{array}$ & $\begin{array}{l}\geq 5 \text { Positive score predictive } \\
\text { value } 85 \%\end{array}$ \\
\hline $\begin{array}{l}\text { Adult Appendicitis } \\
\text { Score }\end{array}$ & $\begin{array}{l}\text { Sammalkorpi } \\
\text { et al. } 2014 \\
\text { [32] }\end{array}$ & $\begin{array}{l}\text { Pain in RLQ } \\
\text { Pain relocation } \\
\text { RLQ tenderness } \\
\text { Men and women }>50 \text { years old } \\
\text { Women }<50 \text { years old } \\
\text { Guarding } \\
\text { Mild } \\
\text { Moderate or severe } \\
\text { Blood leukocyte count }\left(\times 10^{9}\right) \\
\geq 7.2 \text { and }<10.9 \\
\geq 10.9 \text { and }<14.0 \\
\geq 14.0 \\
\text { Proportion of neutrophils }(\%) \\
\geq 62 \text { and }<75 \\
\geq 75 \text { and }<83 \\
\geq 83 \\
\text { CRP (mg/L), symptoms }<24 \mathrm{~h} \\
\geq 4 \text { and }<11 \\
\geq 11 \text { and }<25 \\
\geq 25 \text { and }<83 \\
\geq 83 \\
\text { CRP (mg/l), symptoms }>24 \mathrm{~h} \\
\geq 12 \text { and }<53 \\
\geq 53 \text { and }<152 \\
\geq 152\end{array}$ & $\begin{array}{l}2 \\
2 \\
3 \\
1 \\
2 \\
4 \\
1 \\
2 \\
3 \\
2 \\
3 \\
4 \\
2 \\
3 \\
5 \\
1 \\
2 \\
2 \\
1\end{array}$ & $\begin{array}{l}\text { Score }<11 \text { : low probability } \\
\text { of appendicitis } \\
\text { Score } \geq 16 \text { : high probability } \\
\text { of appendicitis }\end{array}$ \\
\hline $\begin{array}{l}\text { New Approach } \\
\text { to Accurate } \\
\text { Diagnosis } \\
\text { of Acute } \\
\text { Appendicitis }\end{array}$ & $\begin{array}{l}\text { Tzanakis et al. } \\
2005[33]\end{array}$ & $\begin{array}{l}\text { Ultrasound positive for acute } \\
\text { appendicitis } \\
\text { Tenderness in RLQ } \\
\text { Rebound tenderness } \\
\text { Leukocytosis ( }>12,000 \\
\text { WBC/mcL) }\end{array}$ & $\begin{array}{l}6 \\
4 \\
3 \\
2\end{array}$ & $\begin{array}{l}\geq 8 \text { points: } 95.4 \% \text { sensitive, } 97.4 \% \\
\text { specific, and } 96.5 \% \text { accurate for } \\
\text { acute appendicitis }\end{array}$ \\
\hline
\end{tabular}


TABle 1. (CONTINUED)

\begin{tabular}{|c|c|c|c|c|}
\hline Scoring System & Citation & Criteria & Points & Interpretation \\
\hline $\begin{array}{l}\text { Peciatric } \\
\text { Appendicitis } \\
\text { Score }\end{array}$ & $\begin{array}{l}\text { Samuel } \\
\quad 2002[34]\end{array}$ & $\begin{array}{l}\text { RLQ tenderness to cough, } \\
\text { percussion, or hopping } \\
\text { Anorexia } \\
\text { Temperature }\left(\geq 38.0^{\circ} \mathrm{C} / 100.4^{\circ} \mathrm{F}\right) \\
\text { Nausea/vomiting } \\
\text { Tenderness over right iliac fossa } \\
\text { Leukocytosis }\left(>10,000 \times 10^{9}\right. \\
\text { WBC/L) } \\
\text { Left shift }(\text { absolute neutrophil } \\
\text { count }>7,500) \\
\text { Male gender }\end{array}$ & $\begin{array}{l}2 \\
1 \\
1 \\
1 \\
2 \\
1\end{array}$ & $\begin{array}{l}\text { Score of } \leq 5 \text { is not compatible with } \\
\text { the diagnosis of appendicitis; } \\
\text { Score of } \geq 6 \text { is }\end{array}$ \\
\hline RIPASA Score & $\begin{array}{l}\text { Chong et al. } \\
2010[35]\end{array}$ & $\begin{array}{l}\text { Female gender } \\
\text { Age }<40 \\
\text { Age } \geq 40 \\
\text { Right iliac fossa pain } \\
\text { Migration of pain to RLQ } \\
\text { Anorexia } \\
\text { Nausea/vomiting } \\
\text { Duration of symptoms }<48 \text { hours } \\
\text { Duration of symptoms }>48 \mathrm{~h} \\
\text { Right iliac fossa tenderness } \\
\text { Right iliac fossa guarding } \\
\text { Rebound tenderness } \\
\text { Rosving's sign } \\
\text { Fever } \\
\text { Raised white blood cell count } \\
\text { Negative urinalysis } \\
\text { Foreign national registration } \\
\text { identity card }\end{array}$ & $\begin{array}{l}0.5 \\
1 \\
0.5 \\
0.5 \\
0.5 \\
1 \\
1 \\
1 \\
0.5 \\
1 \\
2 \\
1 \\
2 \\
1 \\
1 \\
1 \\
1\end{array}$ & $\begin{array}{l}\text { Score of } 7.5 \text { : sensitivity of } 88.5 \% \\
\text { specificity of } 66.7 \% \text {, and accu- } \\
\text { racy of } 80.5 \%\end{array}$ \\
\hline $\begin{array}{l}\text { Modified Alvarado } \\
\text { Scoring System }\end{array}$ & $\begin{array}{l}\text { Kalan et al. } \\
1994 \text { [36] }\end{array}$ & $\begin{array}{l}\text { Migration of pain to RLQ } \\
\text { Anorexia } \\
\text { Nausea/vomiting } \\
\text { Tenderness in RLQ } \\
\text { Rebound pain } \\
\text { Elevated temperature }\left(>99.1^{\circ} \mathrm{F} \text {; }\right. \\
\left.\quad 37.3^{\circ}\right) \\
\text { Leukocytosis }(>10,000 \\
\left.\text { WBC/ } \mathrm{mm}^{3}\right)\end{array}$ & $\begin{array}{l}1 \\
1 \\
1 \\
2 \\
1 \\
1 \\
2\end{array}$ & $\begin{array}{l}\text { Patients with a score of }<7 \text { were } \\
\text { not considered for surgery } \\
\text { unless there were compelling } \\
\text { reasons to do otherwise Patients } \\
\text { with a score of } 7-9 \text { underwent } \\
\text { appendectomy }\end{array}$ \\
\hline $\begin{array}{l}\text { Ramathibodi Appen- } \\
\text { dicitis Score } \\
\text { (RAMA-AS) }\end{array}$ & $\begin{array}{l}\text { Wilasrusmee } \\
\text { et al. } 2017 \text { [37] }\end{array}$ & $\begin{array}{l}\text { Progression of pain } \\
\text { Aggravation of pain by cough or } \\
\text { movement } \\
\text { Migration of pain to RLQ } \\
\text { Body temperature } \geq 37.8^{\circ} \mathrm{C} \\
\text { Rebound tenderness } \\
\text { Leukocytosis }(>10,000 \\
\left.\text { WBC/ } \mathrm{mm}^{3}\right) \\
\text { Neutrophil }>75 \%\end{array}$ & $\begin{array}{l}1.04 \\
0.78 \\
0.77 \\
1.64 \\
1.53 \\
0.91 \\
0.69\end{array}$ & $\begin{array}{l}\text { Score }<0.64 \text { : very low risk } \\
\text { Score } 0.64-0.84 \text { : low risk } \\
\text { Score } 0.85-1.74 \text { : moderate risk } \\
\text { Score }>1.74 \text { : high risk }\end{array}$ \\
\hline $\begin{array}{l}\text { Delta neutrophil } \\
\text { index }\end{array}$ & $\begin{array}{l}\text { Shin et al } .2017 \\
\text { [38] }\end{array}$ & Delta neutrophil index $>0.2$ & & $\begin{array}{l}\text { Sensitivity } 59.8 \% \text {; specificity } \\
77.1 \%\end{array}$ \\
\hline
\end{tabular}

$\mathrm{CRP}=\mathrm{C}$-reactive protein; $\mathrm{RLQ}=$ right lower quadrant; $\mathrm{WBC}=$ white blood cells.

appendicitis [54,55]. Finally, patients from LMHDICs who have appendicitis may present with a different constellation of symptoms. For example, studies of black South African patients [56,57] have shown that most individuals with histologically proved appendicitis describe non-specific abdominal pain, whereas only a minority report classic migratory pain patterns. Application and assessment of CPRs in LMHDIC settings represent a considerable unmet need and potential for impactful clinical research.

\section{Diagnostic Adjuncts: Imaging and Laboratory Investigations}

Diagnosis of appendicitis remains challenging for physicians throughout the world, even more so in LMHDICs. Although CPRs are useful in diagnosis, no algorithm is sufficiently accurate to identify acute appendicitis or stratify disease severity reliably. Although the addition of ultrasound scanning to diagnostic algorithms is useful in resolving 
Table 2. Established Clinical Prediction Rules for Grading Severity of Appendicitis

\begin{tabular}{|c|c|c|c|c|c|}
\hline Scoring System & Citation & Criteria & Points & & Interpretation \\
\hline $\begin{array}{l}\text { Accuracy of WBC } \\
\text { count and CRP for } \\
\text { assessing severity of } \\
\text { pediatric appendicitis }\end{array}$ & $\begin{array}{l}\text { Siddique et al. } \\
2011 \text { [43] }\end{array}$ & $\begin{array}{c}\mathrm{CRP}>10 \mathrm{mg} / \mathrm{dL} \text { WBC } \\
\text { count } \geq 11 \times 10^{9} / \mathrm{dL}\end{array}$ & & \multicolumn{2}{|c|}{$\begin{array}{r}\text { Sensitivity } 100 \% \text {; } \\
\text { specificity } 20 \%\end{array}$} \\
\hline $\begin{array}{l}\text { Ruptured Appendicitis } \\
\text { Scoring System }\end{array}$ & $\begin{array}{l}\text { Williams et al. } \\
2009 \text { [44] }\end{array}$ & $\begin{array}{l}\text { Generalized abdominal } \\
\text { tenderness } \\
\text { Presences of abscess on CT } \\
\text { Duration of symptoms }>48 \mathrm{~h} \\
\text { WBC count }>19,400 \text { cells } / \mathrm{mcL} \\
\text { Presence of abscess on CT }\end{array}$ & $\begin{array}{l}4 \\
3 \\
3 \\
2 \\
1\end{array}$ & \multicolumn{2}{|c|}{$\begin{array}{l}\text { Score } \geq 9 \text { carries post-test } \\
\text { probability of } 92 \% \\
\text { for acute appendicitis }\end{array}$} \\
\hline $\begin{array}{l}\text { Logistic regression } \\
\text { model to predict } \\
\text { acute uncomplicated } \\
\text { and complicated } \\
\text { appendicitis }\end{array}$ & $\begin{array}{l}\text { Eddama et al. } \\
2019 \text { [45] }\end{array}$ & $\begin{array}{l}\text { CRP } \\
\text { WBC count } \\
\text { Gender } \\
\text { Age }\end{array}$ & & \multicolumn{2}{|c|}{$\begin{array}{l}\text { Logistic regression correctly } \\
\text { classified } 80.8 \% \text { of cases } \\
\text { Calculator available } \\
\text { at www.appendistat.com }\end{array}$} \\
\hline $\begin{array}{l}\text { Scoring system } \\
\text { to distinguish } \\
\text { uncomplicated from } \\
\text { complicated acute } \\
\text { appendicitis }\end{array}$ & $\begin{array}{l}\text { Atema et al. } \\
2015 \text { [46] }\end{array}$ & $\begin{array}{l}\text { Age } \geq 45 \text { y } \\
\text { Body temperature }{ }^{\circ} \mathrm{C} \\
\leq 37 \\
37.1-37.9 \\
\geq 38.0 \\
\text { Duration of symptoms } \geq 48 \mathrm{~h} \\
\text { WBC count }>13 \times 10^{9} / \mathrm{L} \\
\mathrm{CRP}(\mathrm{mg} / \mathrm{L}) \\
\leq 50 \\
51-100 \\
>100 \\
\text { Extraluminal air on } \mathrm{CT} \\
\text { Periappendiceal fluid } \\
\text { on CT or US } \\
\text { Appendicolith on CT or US }\end{array}$ & $\begin{array}{c}\text { With CT } \\
\text { imaging } \\
2 \\
\\
0 \\
2 \\
4 \\
2 \\
2 \\
\\
0 \\
2 \\
3 \\
5 \\
2 \\
\\
2\end{array}$ & $\begin{array}{c}\text { With US } \\
\text { imaging } \\
2 \\
\\
0 \\
2 \\
4 \\
2 \\
2 \\
\\
0 \\
4 \\
5 \\
2 \\
2 \\
2\end{array}$ & $\begin{array}{l}\text { Score } \geq 7 \text { with CT } \\
\text { imaging ( } 22 \text { possible): } \\
\text { Sensitivity } 90.2 \% ; \\
\text { specificity } 70.3 \% \\
\text { Score of } \geq 6 \text { with US } \\
\text { imaging (19 possible): } \\
\text { Sensitivity } 96.6 \% ; \\
\text { specificity } 45.7 \%\end{array}$ \\
\hline Delta neutrophil index & $\begin{array}{l}\text { Shin et al. } \\
2017[38]\end{array}$ & Delta neutrophil index $>0.6$ & & nsitivity 65 & $\%$; specificity $71 \%$ \\
\hline
\end{tabular}

$\mathrm{CRP}=\mathrm{C}$-reactive protein; $\mathrm{CT}=$ computed tomography; $\mathrm{US}=$ ultrasonography; $\mathrm{WBC}=$ white blood cells.

diagnoses in intermediate-risk patients in resource-constrained settings [58,59], the technique is operator dependent, requiring a well-trained evaluator, and is less accurate than crosssectional imaging [24,60,61]. Computed tomography (CT) decreased the rate of incidental appendectomy by nearly $50 \%$ compared with ultrasonography (from $8.1 \%$ to $4.5 \%$ ) in a retrospective study of 3,540 patients [62].

Unfortunately, cross-sectional imaging remains scarce in many LMHDICs. A recent survey of imaging capability revealed only 84 magnetic resonance imaging (MRI) machines for the whole of the West African sub-region [63], and a fourstate, 15-million patient catchment area in Nigeria had only six CT scanners [64]. Another study, in Tanzania, showed that the country had only 5.7 general radiology units per 1 million people (far below the 20 units/1 million people recommended by the World Health Organization) [65]. Even when cross-sectional imaging is available in resourceconstrained settings, its use often is limited in appendicitis because of demands on it for more critical conditions. A review of more than 1,000 appendicitis cases at a tertiary hospital in Nigeria showed only one patient underwent a CT scan [66]. Even in high Human Development-Index Countries (HHDICs), use of CT to diagnose appendicitis differs substantially. A study of 89 centers in the United Kingdom, two in Spain, and one each in Japan, Hong Kong, Australia, and New Zealand revealed that only $12.9 \%$ of patients underwent pre-operative CT [67]. This variation seems to come at a cost of more common incidental appendectomy, as this international cohort had a $20.6 \%$ incidental appendectomy rate [67] compared with an American cohort that had an overall incidental appendectomy rate of 6\% [62]. Finally, although laboratory markers improve diagnosis, reliable pathology and laboratory medical services often are limited in rural areas because of lack of availability and the high associated costs, which many patients cannot afford $[68,69]$. So, despite advances in imaging and laboratory markers, the diagnosis of acute appendicitis relies heavily on presentation and clinical examination, which can be difficult even for experienced physicians.

\section{Sub-Optimal Diagnosis Leads to Worse Outcomes}

Lack of readily accessible and reliable adjuncts for the diagnosis of appendicitis may result in delays in escalation of care for patients with acute appendicitis. These diagnostic delays translate into worse clinical outcomes in a number of studies in LMHDIC populations [70-73]. Delays in diagnosis are further compounded by geographical factors, as patients 
who hail from rural areas often are subject to additional delays before being referred to centers with surgical capabilities. This may help explain disparities in outcomes between rural and urban patients noted in a number of LMHDICs including Nepal [71], Nigeria [72], Pakistan [74], South Africa [75,76], and Ethiopia [77]. One such study [75] noted a higher rate of intensive care unit admission (17\% vs $3 \%$ ), longer median length of hospital stay (9 vs. 3 days), and a higher rate of perforation ( $86 \%$ vs. $39 \%)$ in rural patients than in urban dwellers who presented to a South African hospital with acute appendicitis. These CPRs hold promise as a tool to help rural clinicians triage and refer patients efficiently for definitive surgical care [48] with the goal of closing these gaps in outcomes. However, none of the existing diagnostic algorithms is sufficiently simple or performant for widespread use in highly resource-constrained areas.

\section{Appendectomy}

The rate of complicated appendicitis differs significantly across studies in LMHDIC populations. In South Africa, the complicated appendicitis rate ranges from $11 \%$ [78] to $60 \%$ [75], and a recent systematic review placed the rate of perforation at $36 \%$ [79]. Although non-operative management can be considered in carefully selected patients [23], the risk of failure of antibiotic therapy for uncomplicated appendicitis resulting in appendectomy during index hospitalization has been as high as $5.8 \%$ [80]. Concerningly, the risk of recurrence at one and five years was $27.3 \%$ and $39.1 \%$, respectively [25]. The high risk of antibiotic failure and disease recurrence is compounded by the high rate of complicated appendicitis in LMHDIC populations. Given diagnostic shortcomings and delays in escalation of care, surgical therapy remains an attractive, indeed recommended, option for the treatment of suspected acute appendicitis in LMHDIC populations.

Since its description by Charles McBurney in the 1890 s [81], appendectomy has become the most commonly performed emergency abdominal operation globally [82]. Open appendectomy continues to be a mainstay of treatment in LMHDICs. However, laparoscopic appendectomy [83] has become the procedure of choice for definitive treatment of acute appendicitis in HHDIC populations. The Society of American Gastrointestinal and Endoscopic Surgeons (SAGES) [84], WSES [23], and EAES [24] all recommend laparoscopic appendectomy for the treatment of uncomplicated appendicitis. This recommendation extends to complicated appendicitis, although this view is based on weaker evidence. Laparoscopic appendectomy results in a shorter hospital stay, a lower incidence of surgical site infection (SSI), less pain, and lower overall costs $[23,24]$ than open appendectomy. Laparoscopic appendectomy also is recommended by these groups over open appendectomy in more complicated cases including the obese, the elderly, and patients with other comorbidities [23,24,84].

Laparoscopic appendectomy is a safe and effective strategy for definitive management of appendicitis in LMHDICs $[52,55,71,75,78,85,86]$. Studies in resource-constrained settings have replicated findings from HHDIC cohorts that show a lower rate of SSI with laparoscopic than with open appendectomy $[87,88]$. Additionally, laparoscopic appendectomy proved superior to open appendectomy for the management of complicated appendicitis in LMHDICs [89,90]. Unlike open appendectomy, laparoscopic appendectomy offers the chance to evaluate the entire abdomen for alternative or additional pathology $[24,91,92]$, making it a valuable addition to the LMHDIC surgeon's armamentarium when crosssectional imaging may not be available and the risk of concurrent pathology may be high.

\section{Laparoscopic Appendectomy Improves Outcomes}

A recent international, multicenter, observational cohort study was undertaken by the GlobalSurg Collaborative with the goal of describing surgical approaches to appendectomy and frequencies of post-operative complications in a geographically and socioeconomically diverse population [93]. The study gathered patient-level data from 4,546 patients (2,499 from HHDICs, 1,540 from MHDICs, and 507 from LHDICs) from 52 countries and showed only $8.6 \%$ and $8.1 \%$ of appendectomies performed in MHDIC and LHDICs, respectively, were performed laparoscopically. The study demonstrated a higher risk of complications associated with appendectomy in LHDICs (odds ratio [OR] $1.55 ; 95 \%$ confidence interval [CI] 1.19-1.99; $\mathrm{p}=0.001)$ and MHDICs (OR 1.24; 95\% CI 1.03-1.49; $\mathrm{p}=0.020$ ) compared with HHDICs. The authors also found a significant association between the risk of SSI and development status. Patients from LHDICs had an OR of 3.81 (95\% CI 2.78-5.1; $\mathrm{p}<0.001)$ of developing an SSI whereas those from MHDICs had an OR of 2.99 (95\% CI 2.34-3.84; $\mathrm{p}<0.001)$ compared with those from HHDICs. A recent meta-analysis [94] also showed an elevated rate of SSI (17.9/100 appendectomies; 95\% CI 10.4-25.3 infections/ 100 appendectomies) associated with open appendectomy in LMHDICs. These findings illustrate the importance of targeted interventions to decrease SSIs associated with appendectomy.

Research suggests appendectomy-associated SSI prevention is possible in LMHDIC settings. A randomized trial showed that a single pre-operative dose of cefuroxime sodium and metronidazole prevented $92.2 \%$ of SSIs [95], while another study [96] in Pakistan showed pre-operative antibiotics prevented infection in $94 \%$ of patients. Laparoscopic appendectomy appears to lower the rates of SSI and of complications in general. Although likely underpowered to obtain statistical significance, a retrospective cohort study in Nepal [88] showed a trend toward a lower rate of SSI $(1.8 \%$ vs. $9.8 \% ; \mathrm{p}=0.13)$ similar to the aforementioned meta-analysis, which revealed a decrease in the pooled SSI rate to 8.8/100 laparoscopic appendectomies (95\% CI 4.513.2/100 operations). The GlobalSurg Collaborative study found laparoscopic appendectomy to be associated with a lower rate of SSI (OR 0.22; 95\% CI 0.14-0.33; p <0.001) and fewer overall complications (OR 0.55 ; 95\% CI $0.42-$ $0.71 ; \mathrm{p}<0.001)$ compared with open appendectomy. These data translate into an absolute risk reduction of any complication of $6 \%$ (number needed to treat [NNT] of 16) for laparoscopic appendectomy for uncomplicated appendicitis and an absolute risk reduction of $17 \%$ (NNT of 8 ) in the case of perforated appendicitis [93]. These data underscore the utility of laparoscopic appendectomy in improving outcomes in resource-constrained settings. 


\section{Adoption of Laparoscopic Appendectomy in LMHDICs}

Although data support the use of laparoscopic appendectomy in LMHDICs to reduce complications and improve clinical outcomes, adoption of this procedure in these settings remains slow [93]. This is likely a result of the legacy of a number of obstacles including unfamiliarity with laparoscopic techniques by senior surgeons, lack of training, and high costs associated with capital and disposable equipment [92]. Recent publications by authors from LMHDICs outlining clinical, economic, and systemic advantages of laparoscopy in resource-constrained settings [97] suggest a change in attitudes toward laparoscopy by surgeons in these countries. Additionally, a multitude of low-cost, high-fidelity trainers and simulators are now available to help increase comfort with basic laparoscopic skills [92].

Laparoscopy affords diagnostic advantages that have proved useful in identifying concurrent or alternative pathology [64]; and when compared with ultrasonography, CT, and MRI, diagnostic laparoscopy is cost effective (equipment cost ratio of 1:500:2500:4500) with a low complication rate $(0.09 \%)$ [98]. Laparoscopic appendectomy was costeffective compared with open appendectomy in a Colombian cohort with an incremental cost-effectiveness ratio (ICER) of US\$25.86 [99]. Moreover, in a Nigerian population, the approach decreased the rate of incidental appendectomy and the length of the post-operative hospital stay [72]. These findings illustrate the urgent need for a comprehensive costbenefit analysis of laparoscopic appendectomy across LMHDICs.

A number of interesting modifications to laparoscopic appendectomy have been proposed to facilitate wider adoption in resource-constrained settings. A gasless technique utilizing modified, reusable open surgical instruments through gel ports eliminates the need for costly insufflators, disposable instruments, and bottled gases [100]. The procedure can be performed under spinal anesthesia, and as of 2016, the authors had performed 113 appendectomies using this approach. Other surgeons [101] conducted a randomized trial of 72 patients comparing open appendectomy $(n=36)$ and laparoscopic intra-corporeal ligation with 2-0 silk suture $(n=36)$ and specimen extraction using a bag fashioned from a glove in the operating room. The authors reported one SSI $(1.3 \%)$ in the laparoscopy group and five SSIs (13.9\%) in the open surgery group and reported a lower overall cost, although specific figures were not provided. Finally, another group of surgeons [102] used an autoclavable, reusable endoring applicator (ERA) to apply Falope rings to the appendix after skeletonization of the mesoappendix with diathermy. The appendix was then divided and removed through the inner lumen of the ERA, obviating specimen containment on withdrawal. The procedure is inexpensive (Falope rings were Rs. 50 [US \$0.70] at the time of publication), but the procedure cannot be performed on appendices $>8 \mathrm{~mm}$ in diameter nor on friable or perforated organs.

Some of these cost-saving methods have been evaluated by surgical societies. Based on low-grade evidence (evidence level 3), the WSES recommends (grade of recommendation B) that electrocoagulation or bipolar energy be used for mesoappendiceal dissection, as this is the most cost-effective, and there are no differences in outcomes between them and other dissection techniques. The group also recommends that the use of endoloops be considered as an additional costlowering method (evidence level 3; grade of recommendation B) [23]. On the contrary, the EAES recommends the use of a stapler or suture over clips or endoloops when the base of the appendix is inflamed, necrotic, or perforated [24].

\section{Conclusions}

Acute appendicitis remains one of the leading causes of abdominal surgical emergencies globally. The incidence of appendicitis is increasing in LMHDICs. Although a proportion of patients can be treated successfully with nonoperative management consisting of antibiotics, supportive therapy, and close observation, current diagnostic algorithms lack the granularity to identify these patients accurately. Shortcomings in current diagnostic strategies, combined with delays in obtaining surgical care inherent in many LMHDIC healthcare systems, make prompt surgical

Table 3. Research Deficits in Understanding of Appendicitis IN Low- AND MidDle-Human DEVELOPMENT-INDEX COUNTRIES (LMHDICs)

Characterization Disease incidence and stratification of appendicitis Clinical presentation

Incidence of non-appendicitis causes of right lower quadrant abdominal pain Epidemiology

Improved Evaluation of performance of existing diagnostics CPRs in LMHDIC populations

Development of new CPRs based on data collected from large cohorts

Development and validation of simple, effective triage tools to facilitate rapid identification and referral of rural patients to hospitals with surgical capacity

Needs assessments

Identify critical deficiencies in imaging and laboratory medical services

Identify critical deficiencies in laparoscopic surgical infrastructure for both capital and consumable equipment

Identify training gaps in senior surgeons and trainees preventing adoption of laparoscopic techniques

Identify supply chain obstacles to widespread adoption of laparoscopic surgery

Surgical Detailed understanding of current outcomes surgical complication rates in order to target interventions

Understanding of benefits and challenges associated with early adoption of laparoscopic appendectomy

Evaluation of the safety of cost saving modifications to laparoscopic appendectomy

Cost Comprehensive regional and global efficacy cost-effectiveness studies examining the widespread implementation of laparoscopic appendectomy

Impact of cost-saving modifications to laparoscopic appendectomy on overall cost

$\mathrm{CPR}=$ clinical prediction rules. 
care the mainstay of the treatment of acute appendicitis. Laparoscopic appendectomy leads to better outcomes than open appendectomy for these patients and when available should be the surgical technique of choice in resourceconstrained settings. Table 3 identifies areas of focus for additional research aimed at improving the diagnosis and treatment of appendicitis in a cost-effective manner in order to optimize outcomes in LMHDICs.

\section{Author Disclosure Statement}

The authors have no financial disclosures.

Both authors collected the data and wrote the article.

\section{References}

1. Jones MW, Lopez RA, Deppen JG. Appendicitis. In: StatPearls. Treasure Island (FL): StatPearls Publishing; 2019.

2. Ferris M, Quan S, Kaplan BS, et al. The global incidence of appendicitis: A systematic review of population-based studies. Ann Surg 2017;266:237-241.

3. Adamidis D, Roma-Giannikou E, Karamolegou K, et al. Fiber intake and childhood appendicitis. Int J Food Sci Nutr 2000;51:153-157.

4. Burkitt DP. Some diseases characteristic of modern Western civilization. Br Med J 1973;1:274-278.

5. Kaplan GG, Tanyingoh D, Dixon E, et al. Ambient ozone concentrations and the risk of perforated and nonperforated appendicitis: A multicity case-crossover study. Environ Health Perspect 2013;121:939-943.

6. Kaplan GG, Dixon E, Panaccione R, et al. Effect of ambient air pollution on the incidence of appendicitis. CMAJ 2009;181:591-597.

7. Singh RB, Grover A. Urban industrial development, environmental pollution, and human health: A case study of East Delhi. In: Akhtar R, editor. Climate Change and Human Health Scenario in South and Southeast Asia Cham: Springer International Publishing; 2016:113-130.

8. Zhong D, Brower-Sinning R, Firek B, Morowitz MJ. Acute appendicitis in children is associated with an abundance of bacteria from the phylum fusobacteria. J Pediatr Surg 2014;49:441-446.

9. Swidsinski A, Dörffel Y, Loening-Baucke V, et al. Mucosal invasion by fusobacteria is a common feature of acute appendicitis in Germany, Russia, and China. Saudi J Gastroenterol 2012;18:55-58.

10. Orlova E, Yeh A, Shi M, et al. Genetic association and differential expression of PITX2 with acute appendicitis. Hum Genet 2019;138:37-47.

11. Addiss DG, Shaffer N, Fowler BS, Tauxe RV. The epidemiology of appendicitis and appendectomy in the United States. Am J Epidemiol 1990;132:910-925.

12. Luckmann R. Incidence and case fatality rates for acute appendicitis in California: A population-based study of the effects of age. Am J Epidemiol 1989;129:905-918.

13. Alder AC, Fomby TB, Woodward WA, et al. Association of viral infection and appendicitis. Arch Surg 2010;145: $63-71$.

14. Andersson R, Hugander A, Thulin A, et al. Indications for operation in suspected appendicitis and incidence of perforation. BMJ 1994;308:107-110.

15. Livingston EH, Woodward WA, Sarosi GA, Haley RW. Disconnect between incidence of nonperforated and per- forated appendicitis: Implications for pathophysiology and management. Ann Surg 2007;245:886-892.

16. Drake FT, Mottey NE, Farrokhi ET, et al. Time to appendectomy and risk of perforation in acute appendicitis. JAMA Surg 2014;149:837-844.

17. Rivera-Chavez FA, Peters-Hybki DL, Barber RC, et al. Innate immunity genes influence the severity of acute appendicitis. Ann Surg 2004;240:269-277.

18. Sallinen V, Akl EA, You JJ, et al. Meta-analysis of antibiotics versus appendicectomy for non-perforated acute appendicitis. Br J Surg 2016;103:656-667.

19. Poon SHT, Lee JWY, Ng KM, et al. The current management of acute uncomplicated appendicitis: Should there be a change in paradigm? A systematic review of the literature and analysis of treatment performance. World J Emerg Surg 2017;12:46.

20. Velanovich V, Satava R. Balancing the normal appendectomy rate with the perforated appendicitis rate: Implications for quality assurance. Am Surg 1992;58:264-269.

21. Blomqvist PG, Andersson RE, Granath F, et al. Mortality after appendectomy in Sweden, 1987-1996. Ann Surg 2001;233:455-460.

22. Fallon SC, Kim ME, Hallmark CA, et al. Correlating surgical and pathological diagnoses in pediatric appendicitis. J Pediatr Surg 2015;50:638-641.

23. Di Saverio S, Birindelli A, Kelly MD, et al. WSES Jerusalem guidelines for diagnosis and treatment of acute appendicitis. World J Emerg Surg 2016;11:34.

24. Gorter RR, Eker HH, Gorter-Stam MAW, et al. Diagnosis and management of acute appendicitis: EAES consensus development conference 2015. Surg Endosc 2016;30: 4668-4690.

25. Salminen P, Tuominen R, Paajanen H, et al. Five-year follow-up of antibiotic therapy for uncomplicated acute appendicitis in the APPAC randomized clinical trial. JAMA 2018;320:1259-1265.

26. Andersson RE. The natural history and traditional management of appendicitis revisited: Spontaneous resolution and predominance of prehospital perforations imply that a correct diagnosis is more important than an early diagnosis. World J Surg 2007;31:86-92.

27. Flum DR, Koepsell T. The clinical and economic correlates of misdiagnosed appendicitis: Nationwide analysis. Arch Surg 2002;137:799-804.

28. Buonpane C, Goldstein S. Defining the disease: Uncomplicated versus complicated appendicitis. In: Hunter CJ, editor. Controversies in Pediatric Appendicitis. Cham: Springer International Publishing; 2019:7-11.

29. Alvarado A. A practical score for the early diagnosis of acute appendicitis. Ann Emerg Med 1986;15:557-564.

30. Andersson M, Andersson RE. The Appendicitis Inflammatory Response Score: A tool for the diagnosis of acute appendicitis that outperforms the Alvarado score. World J Surg 2008;32:1843-1849.

31. Mikaere H, Zeng I, Lauti M, et al. Derivation and validation of the APPEND score: An acute appendicitis clinical prediction rule. ANZ J Surg 2018;88:E303-E307.

32. Sammalkorpi HE, Mentula P, Leppäniemi A. A new adult appendicitis score improves diagnostic accuracy of acute appendicitis: A prospective study. BMC Gastroenterol 2014; $14: 114$.

33. Tzanakis NE, Efstathiou SP, Danulidis K, et al. A new approach to accurate diagnosis of acute appendicitis. World J Surg 2005;29:1151-1157. 
34. Samuel M. Pediatric appendicitis score. J Pediatr Surg 2002;37:877-881.

35. Chong CF, Adi MIW, Thien A, et al. Development of the RIPASA score: A new appendicitis scoring system for the diagnosis of acute appendicitis. Singapore Med J 2010;51: 220-225.

36. Kalan M, Talbot D, Cunliffe WJ, Rich AJ. Evaluation of the modified Alvarado score in the diagnosis of acute appendicitis: A prospective study. Ann R Coll Surg Engl 1994;76:418-419.

37. Wilasrusmee C, Siribumrungwong B, Phuwapraisirisan S, et al. Developing and validating of Ramathibodi Appendicitis Score (RAMA-AS) for diagnosis of appendicitis in suspected appendicitis patients. World J Emerg Surg 2017;12:49.

38. Shin DH, Cho YS, Cho GC, et al. Delta neutrophil index as an early predictor of acute appendicitis and acute complicated appendicitis in adults. World J Emerg Surg 2017;12:32

39. Ohle R, O'Reilly F, O'Brien KK, et al. The Alvarado score for predicting acute appendicitis: A systematic review. BMC Med 2011;9:139.

40. Kularatna M, Lauti M, Haran C, et al. Clinical prediction rules for appendicitis in adults: Which is best? World $\mathrm{J}$ Surg 2017;41:1769-1781.

41. Chung PHY, Dai K, Yang Z, Wong KKY. Validity of Alvarado Score in predicting disease severity and postoperative complication in pediatric acute appendicitis. World J Pediatr Surg [Internet]. February 1, 2019;2(1) (cited November 24, 2019). Available at: https:// wjps.bmj.com/content/2/1/e000003

42. Deiters A, Drozd A, Parikh P, et al. Use of the Alvarado Score in elderly patients with complicated and uncomplicated appendicitis. Am Surg 2019;85:397-402.o

43. Siddique K, Baruah P, Bhandari S, et al. Diagnostic accuracy of white cell count and C-reactive protein for assessing the severity of paediatric appendicitis. JRSM Short Rep 2011;2(7):59.

44. Williams RF, Blakely ML, Fischer PE, et al. Diagnosing ruptured appendicitis preoperatively in pediatric patients. J Am Coll Surg 2009;208(5):819-828.

45. Eddama M, Fragkos KC, Renshaw S, et al. Logistic regression model to predict acute uncomplicated and complicated appendicitis. Ann R Coll Surg Engl 2019;101: 107-118.</BIBTX<

46. Atema JJ, van Rossem CC, Leeuwenburgh MM, et al. Scoring system to distinguish uncomplicated from complicated acute appendicitis. Br J Surg 2015;102:979-990.

47. N N, Mohammed A, Shanbhag V, et al. A comparative study of RIPASA Score and Alvarado Score in the diagnosis of acute appendicitis. J Clin Diagn Res 2014;8: $\mathrm{NC03-NC05.}$

48. Kong VY, van der Linde S, Aldous C, et al. The accuracy of the Alvarado score in predicting acute appendicitis in the black South African population needs to be validated. Can J Surg 2014;57:E121-E125.

49. Kanumba ES, Mabula JB, Rambau P, Chalya PL. Modified Alvarado Scoring System as a diagnostic tool for acute appendicitis at Bugando Medical Centre, Mwanza, Tanzania. BMC Surg 2011;11:4.

50. United Nations, Department of Economic and Social Affairs, Population Division. Population 2030: Demographic challenges and opportunities for sustainable development planning (ST/ESA/SER.A/389). 2015.
51. Kulik DM, Uleryk EM, Maguire JL. Does this child have appendicitis? A systematic review of clinical prediction rules for children with acute abdominal pain. J Clin Epidemiol 2013;66:95-104.

52. Chamisa I. A clinicopathological review of 324 appendices removed for acute appendicitis in Durban, South Africa: A retrospective analysis. Ann R Coll Surg Engl 2009;91:688-692.

53. Mehndiratta S. Typhoid fever with acute abdominal pain masquerading as surgical emergency! Int J Adv Med Health Res 2016;3:31.

54. Clarke DL, Thomson SR, Bissetty T, et al. A single surgical unit's experience with abdominal tuberculosis in the HIV/AIDS era. World J Surg 2007;31:1087-1098.

55. Cunnigaiper ND, Raj P, Ganeshram P, Venkatesan V. Does Ochsner-Sherren regimen still hold true in the management of appendicular mass? Ulus Travma Acil Cerrahi Derg 2010;16:43-46.

56. Madiba TE, Haffejee AA, Mbete DL, et al. Appendicitis among African patients at King Edward VIII Hospital, Durban, South Africa: A review. East Afr Med J 1998;75: 81-84.

57. Kong VY, Bulajic B, Allorto NL, et al. Acute appendicitis in a developing country. World J Surg 2012;36:20682073.

58. Samir M, Hefzy M, Gaber M, Moghazy K. Added value of graded compression ultrasound to the Alvarado score in cases of right iliac fossa pain. Afr J Emerg Med 2016;6: 138-143.

59. Chada CKR, Malepati S, Kandati J, Satish S. Diagnosis and management of acute appendicitis by Alvarado scoring with ultrasonography as supportive tool. Int Surg J 2017;4:2806-2810.

60. Mostbeck G, Adam EJ, Nielsen MB, et al. How to diagnose acute appendicitis: Ultrasound first. Insights Imag 2016;7:255-263.

61. Reich B, Zalut T, Weiner SG. An international evaluation of ultrasound vs. computed tomography in the diagnosis of appendicitis. Int J Emerg Med 2011;4:68.

62. SCOAP Collaborative, Cuschieri J, Florence M, Flum DR, et al. Negative appendectomy and imaging accuracy in the Washington State Surgical Care and Outcomes Assessment Program. Ann Surg 2008;248:557-563.

63. Ogbole GI, Adeyomoye AO, Badu-Peprah A, et al. Survey of magnetic resonance imaging availability in West Africa. Pan Afr Med J 2018;30:240.

64. Adisa AO, Lawal OO, Adesunkanmi A-RK, Adejuyigbe O. Impact of introduction of laparoscopic surgery on management of unresolved intra-abdominal malignancies in a West African hospital. World J Surg 2014;38:2519-2524.

65. Ngoya PS, Muhogora WE, Pitcher RD. Defining the diagnostic divide: An analysis of registered radiological equipment resources in a low-income African country. Pan Afr Med J 2016;25:99.

66. Afuwape OO, Ayandipo OO, Soneye O, Fakoya A. Pattern of presentation and outcome of management of acute appendicitis: A 10-year experience. Neurol Sci 2018;15:171.

67. National Surgical Research Collaborative. Multicentre observational study of performance variation in provision and outcome of emergency appendicectomy. Br J Surg 2013;100:1240-1252.

68. Nkengasong JN, Yao K, Onyebujoh P. Laboratory medicine in low-income and middle-income countries: Progress and challenges. Lancet 2018;391:1873-1875. 
69. Wilson ML, Fleming KA, Kuti MA, et al. Access to pathology and laboratory medicine services: A crucial gap. Lancet 2018;391:1927-1938.

70. Ohene-Yeboah M, Togbe B. An audit of appendicitis and appendicectomy in Kumasi, Ghana. West Afr J Med 2006; 25:138-143.

71. Pokharel N, Sapkota P, Kc B, Rimal S, Thapa S, Shakya R. Acute appendicitis in elderly patients: A challenge for surgeons. Nepal Med Coll J 2011;13:285-288.

72. Adisa AO, Alatise OI, Arowolo OA, Lawal OO. Laparoscopic appendectomy in a Nigerian teaching hospital. JSLS 2012;16:576-580.

73. Willmore WS, Hill AG. Acute appendicitis in a Kenyan rural hospital. East Afr Med J 2001;78:355-357.

74. Fahim F, Shirjeel S. A comparison between presentation time and delay in surgery in simple and advanced appendicitis. J Ayub Med Coll Abbottabad 2005;17: 37-39.

75. Kong VY, Sartorius B, Clarke DL. Acute appendicitis in the developing world is a morbid disease. Ann R Coll Surg Engl 2015;97:390-395.

76. Rogers AD, Hampton MI, Bunting M, Atherstone AK. Audit of appendicectomies at Frere Hospital, Eastern Cape. S Afr J Surg 2008;46:74-77.

77. Hagos M. Pattern of acute appendicitis in Mekelle, Ethiopia. Ethiop Med J 2014;52:113-118.

78. Yang E, Cook C, Kahn D. Acute appendicitis in the public and private sectors in Cape Town, South Africa. World J Surg 2015;39:1700-1707.

79. Yang E, Kahn D, Cook C. Acute appendicitis in South Africa: A systematic review. S Afr J Surg 2015;53(3 and 4):31-38.

80. Salminen P, Paajanen H, Rautio T, et al. Antibiotic therapy vs appendectomy for treatment of uncomplicated acute appendicitis: The APPAC randomized clinical trial. JAMA 2015;313:2340-2348.

81. McBurney C. IV. The incision made in the abdominal wall in cases of appendicitis, with a description of a new method of operating. Ann Surg 1894;20:38-43.

82. GlobalSurg Collaborative. Mortality of emergency abdominal surgery in high-, middle- and low-income countries. Br J Surg 2016;103:971-988.

83. Semm K. Endoscopic appendectomy. Endoscopy 1983; 15:59-64.

84. Korndorffer JR Jr, Fellinger E, Reed W. SAGES guideline for laparoscopic appendectomy. Surg Endosc 2010;24: 757-761.

85. Malik AM, Talpur AH, Laghari AA. Video-assisted laparoscopic extracorporeal appendectomy versus open appendectomy. J Laparoendosc Adv Surg Tech A 2009; 19: 355-359.

86. Khalil J, Muqim R, Rafique M, Khan M. Laparoscopic versus open appendectomy: A comparison of primary outcome measures. Saudi J Gastroenterol 2011;17:236240 .

87. Utpal D. Laparoscopic versus open appendectomy in West Bengal, India. Chin J Dig Dis 2005;6:165-169.

88. Batajoo H, Hazra NK. Laparoscopic versus open appendectomy in acute appendicitis. J Nepal Health Res Counc 2012;10:239-242.
89. Mohamed AA, Mahran KM. Laparoscopic appendectomy in complicated appendicitis: Is it safe? J Minim Access Surg 2013;9:55-58.

90. Khiria LS, Ardhnari R, Mohan N, et al. Laparoscopic appendicectomy for complicated appendicitis: Is it safe and justified?: A retrospective analysis. Surg Laparosc Endosc Percutan Tech 2011;21:142-145.

91. Patel SC, Jumba GF, Akmal S. Laparoscopic appendicectomy at the Aga Khan Hospital, Nairobi. East Afr Med J 2003;80:447-451.

92. Alfa-Wali M, Osaghae S. Practice, training and safety of laparoscopic surgery in low and middle-income countries. World J Gastrointest Surg. 2017 Jan 27;9(1):13-8.

93. GlobalSurg Collaborative. Laparoscopy in management of appendicitis in high-, middle-, and low-income countries: A multicenter, prospective, cohort study. Surg Endosc 2018;32:3450-3466.

94. Foster D, Kethman W, Cai LZ, et al. Surgical site infections after appendectomy performed in low and middle Human Development-Index countries: A systematic review. Surg Infect 2018;19:237-244.

95. Rafiq MS, Khan MM, Khan A, Jan H. Evaluation of postoperative antibiotics after non-perforated appendectomy. J Pak Med Assoc 2015;65:815-817.

96. Ali K, Latif H, Ahmad S. Frequency of wound infection in non-perforated appendicitis with use of single dose preoperative antibiotics. J Ayub Med Coll Abbottabad 2015; 27:378-380.

97. Chao TE, Mandigo M, Opoku-Anane J, Maine R. Systematic review of laparoscopic surgery in low- and middleincome countries: Benefits, challenges, and strategies. Surg Endosc 2016;30:1-10.

98. Udwadia TE. Diagnostic laparoscopy. Surg Endosc 2004; 18:6-10.

99. Ruiz-Patiño A, Rey S, Molina G, et al. Cost-effectiveness of laparoscopic versus open appendectomy in developing nations: A Colombian analysis. J Surg Res 2018;224:33-37.

100. Gnanaraj J, Rhodes M. Laparoscopic surgery in middleand low-income countries: Gasless lift laparoscopic surgery. Surg Endosc 2016;30:2151-2154.

101. Aziret M, Çetinkünar S, Erdem H, et al. Comparison of open appendectomy and laparoscopic appendectomy with laparoscopic intracorporeal knotting and glove endobag techniques: A prospective observational study. Turk J Surg 2017;33:258-266.

102. Ali IV, Maliekkal JI. Laparoscopic appendicectomy using endo-ring applicator and fallope rings. Saudi J Gastroenterol 2009; 15:39-41.

Address correspondence to: Dr. Joseph D. Forrester Division of General Surgery

Department of Surgery Stanford University H3591

300 Pasteur Drive Stanford, CA 94305

USA

E-mail: jdf1@stanford.edu 